\title{
COHESIVE MARKERS IN SOCIAL MEDIA DISCOURSE: A CASE IN INDONESIAN FACEBOOK CONVERSATIONS
}

\author{
M. Zainal Muttaqien ${ }^{I} \quad$ Amir Ma'ruf ${ }^{2} \quad$ Tofan Dwi Hardjanto ${ }^{3}$ \\ Universitas Gadjah Mada ${ }^{l, 2,3}$ \\ m.zainal.muttaqien@mail.ugm.ac.id ${ }^{l}$,amir_maruf@ugm.ac.id ${ }^{2}$,deha@ugm.ac.id ${ }^{3}$
}

\begin{abstract}
The emergence of social media as a new channel of communication has produced a new form of discourse which has different characteristics compared to the formerly established conventional discourses. These differences do not only lie in how the messages are delivered but also in their structural components which contribute to the unity of the text, namely cohesion and coherence. Cohesion is realized by language units (words, phrases, or clauses) known as cohesive markers which indicate the relationship between parts of discourse either grammatically or lexically. This article aims at describing the composition and distribution of cohesive markers within the Facebook conversations along with their roles in determining the characteristics of the discourse. The results show that the cohesive system of Facebook conversations are dominated by references, ellipses, repetitions, and conjunctions. The frequent occurrences of certain referential cohesive markers indicate Facebook conversations as typical of interactive discourse whereas numerous ellipses and particular conjunctions reflect the informal mode of communication carried out through the social media. On the other hand, various repetitions show the existence of topical cohesion within the conversations.
\end{abstract}

Keywords: cohesion, conversation, social media, Facebook

\begin{abstract}
Abstrak
Munculnya media sosial sebagai sebuah saluran komunikasi yang baru telah menghasilkan suatu bentuk wacana baru yang memiliki ciri-ciri yang berbeda dari wacana-wacana sebelumnya yang lebih konvensional. Perbedaan ini tidak hanya terletak pada pesan yang disampaikan tetapi juga pada komponen-komponen struktural yang berkontribusi pada kesatuan teks, yaitu kohesi dan koherensi. Kohesi dinyatakan dengan satuan bahasa (kata, frasa, atau klausa), yang dikenal dengan pemarkah kohesif untuk menunjukkan adanya hubungan antara bagian-bagian wacana, baik secara gramatikal maupun leksikal. Makalah ini bertujuan untuk menjelaskan komposisi dan distribusi pemarkah kohesif dalam percakapan Facebook, dan juga peran pemarkah tersebut dalam menentukan ciri-ciri wacana. Hasil penelitian ini menunjukkan bahwa sistem kohesi dalam percakapan Facebook didominasi oleh referensi, elipsis, repetisi, dan konjungsi. Seringnya kemunculan pemarkah kohesif refensial menunjukkan bahwa percakapan dalam Facebook merupakan wacana interaktif yang khas. Penggunaan elipsis dan konjungsi tertentu yang cukup banyak mengindikasikan sebuah komunikasi informal yang disampaikan melalui media sosial. Penggunaan repetisi menunjukkan adanya kohesi topikal dalam percakapan tersebut.
\end{abstract}

Kata kunci: kohesi, percakapan, media sosial, Facebook 


\section{INTRODUCTION}

The advancement of technology, especially the Internet, has raised new ways of communication. According to Holt (2004: 14-15), internet communication has created a climate in which multiplicities of connections provide a great number and variety of opportunities for ideas to be shared. As stated by Thurlow, Lengel, \& Tomic (2004: 31), the Internet is not a single communication technology but rather a collection of different technologies for communicating. It is a system comprised of many subsystems, each of which has its own genre or type of communication. There is no single way of communicating on the Internet. New ways of communicating through the Internet are evolving and emerging all the time in response to both technological and social changes. Therefore, almost all forms of communication in the world have now been duplicated and can be found in the Internet, from face-to-face conversations to radio-and-television broadcasts, and from telephone calls to letter writings. Simply, the real and virtual world can be said to be in parallel to one another despite some of their practical differences.

One channel of communication that is currently popular in the Internet is social media. Carr \& Hayes (2015: 19) define social media as "internet-based, disentrained, and persistent channels of mass personal communication facilitating perceptions of interactions among users, deriving value primarily from user-generated content". According to Rohmadi (2016: 1), social media give possibilities to their users for establishing social relationships by making interactions, sharing information as well as building cooperation. Nowadays, social media have become a daily need for making online conversations as well as sharing electronic materials. By social media, people can share their own ideas to which others can give responses.

Currently, there are lots of social media platforms available for different purposes, from just chatting-up to photo-and-video sharing, such as WhatsApp, Facebook, Twitter, Instagram, YouTube, LinkedIn, and some others. Based on their functions, Rohmadi (2016) classifies social media into social networks, forums, blogs, microblogs, social bookmarkings, social photo-and-video sharing, dan wikis. Facebook as one of the most popular social media can be included into social networking site (SNS). Further, Boyd \& Ellison (2013: 157) define social networking site as "a networked communication platform in which participants (1) have uniquely identifiable profiles that consist of user-supplied content, content provided by other users, and/or system-provided data; (2) can publicly articulate connections that can be viewed and traversed by others; and (3) can consume, produce, and/or interact with streams of usergenerated content provided by their connections on the site".

The popularity of Facebook as a social media is among others indicated by its huge number of active users. According to Statista (2019a), up to April 2019, Facebook maintains its position as a global leading social media by collecting not less than 2.3 billion of monthly active users exceeding YouTube (1,9 billion), WhatsApp (1,6 billion), dan Instagram ( 1 billion). In the same period, Statista (2019b) also positioned Indonesia in the third place among countries with the biggest number of Facebook users with 120 million of population, following India and the United States. Based on the data released by Statcounter: GlobalStats (2019) up to June 2019, Facebook has also dominated $43 \%$ market share of social media in Indonesia by overcoming YouTube (20\%) and Twitter (14\%). This hegemony has positioned Facebook as an influential brand worth considering for any current research on social media. 


\section{Cohesion and coherence}

The existence of this new online media, such as Facebook, has automatically produced a new form of discourse that is, to some extent, different from the conventional ones which have previously established in the history of language use. Some of the differences lies in the cohesion and coherence as two elements that build the unity of a text. De Beaugrande (1981: 312) even includes cohesion and coherence into seven discursive standards besides intentionality, acceptability, informability, situationality, and intertextuality. However, there remains a controversy about the differences between these two elements. Some experts count cohesion and coherence as the same thing and prefer using one of the terms - cohesion or coherence only - to refer to two different perceptions whereas the others see them as two separated entities. It is also frequently questioned whether cohesion only deals with the structure of a text or it has something to do with meaning as well.

Halliday \& Hasan (1976: 4) tend to use the term 'cohesion' rather than 'coherence' for describing the relations between parts of a text, even though what they refer to sometimes includes coherence properties. They view cohesion as relations of meaning that exist within the text and its concept is semantic rather than structural or syntactical. However, the notion of cohesion as a semantic relation here seems contradictive to its detailed descriptions into grammatical and lexical types which involve syntactical elements. Martin (1992) also uses the same term: 'cohesion' is used to refer to the relation between either form or meaning within a text. He even sees cohesion restrictedly as a kind of conjunction between sentences.

Meanwhile, Widdowson (1978: 28-29) views cohesion and coherence as two different entities. He defines the former as the overt relationship expressed through sentences whereas the latter constitutes the relationship between the illocutionary acts which propositions - not always overtly linked - are being used to perform. Later, De Beaugrande \& Dressler (1981: 3-4) make this distinction even clearer by defining cohesion as the ways in which the components of the surface text - i.e. the actual words we hear or see - are mutually connected within a sequence. He contrasts it with coherence as the ways in which the components of the textual world - i.e configuration of concepts and relations which underlie the surface text - are mutually accessible and relevant.

Hoey (1991: 12) further distinguishes cohesion and coherence by emphasizing that cohesion is a property of the text whereas coherence is a facet of reader's evaluation to the text. Therefore, coherence is a sort of judgement that is subjective and may vary from one reader to another. In parallel to Hoey (1991), Thompson (2014: 215) also views cohesion as a textual phenomenon, that is linguistic devices by which speaker can signal the coherence of a text, whereas coherence is a mental phenomenon placed in the mind of the writer and reader. Therefore, unlike cohesion, coherence cannot be identified and quantified.

By considering various perspectives above, cohesion and coherence can be considered as two separated aspects in discourse. However, they have a close relationship since both are two significant elements that build the unity of a text. In addition, cohesion can also be seen as a part of coherence in which the emergence of the former depends on the existence of the latter. Cohesion as a structural or lexical tie between two parts of a text has the function to mark coherence, that is the relation of meanings established within the text. 


\section{Types of cohesion}

Similar to its definitions, the types of cohesion also vary according to the classifications proposed by different experts. One that has become primary reference for analyzing cohesion is Halliday \& Hasan's (1976) theory which distinguishes cohesion from grammatical and lexical point of view. Grammatical cohesion includes reference, substitution, ellipsis, and conjunction as its devices whereas lexical cohesion involves reiteration and collocation. Reiteration itself is indicated by the use of the same words, synonyms or near synonyms, superordinates, and general words. This classification has then become the basis of systemic functional linguistic (SFL) viewpoint on cohesion developed by Halliday and other scholars.

Later, Halliday \& Hasan (1985) updated their perspective on textual cohesion by introducing the terms co-reference, co-classification, and co-extension to classify different cohesive devices based on their tie relations. Grammatically, co-reference is constituted by referential cohesive devices - i.e. pronominals, demonstratives, definite articles, and comparative - whereas co-classification is constituted by nominal, verbal, or clausal substitution and ellipsis. Co-extension itself is a form of lexical cohesive relation. Along with coclassification, it represents generic relations, namely repetition, synonymy, antonymy, and meronymy. Co-reference and co-classification relation can also be manifested instantially by lexical cohesive devices, such in equivalence, naming, and semblance. These all represent componential relations which are parallel to organic relations. Organic relations themselves comprise conjunctives and adjacency pairs as grammatical cohesive devices and continuatives as the lexical ones. Both these relations are typical of non-structural cohesion as the opposite of structural cohesion which covers paralellism, theme-rheme development, and given-new organization.

Another perspective of cohesive relations comes from Martin (1992). Similar to Halliday \& Hasan (1976), Martin divides cohesion principally into two main groups as well, i.e. grammatical and lexical cohesion. However, its structure is taxonomically different. Here, grammatical cohesion comprises referential item, substitution, ellipsis, and conjunction. Conjunction itself can further be subdivided into internal and external conjunctions as well as logicosemantics which consists of elaboration, extension, and enhancement. Meanwhile, lexical cohesion can be distinguished into taxonomic and non-taxonomic. The former can further be differentiated into superordination and composition whereas the latter comprises nuclear experiential and activity expectation. Superordination can then be subdivided into inclusion (i.e. hyponymy, co-hyponymy) and similarity (i.e. repetition, synonymy, antonymy,) whereas composition subordinates collectivity, consistency, and constitution (i.e. meronymy, comeronymy).

Even though there are different perspectives on cohesion, people generally agree on its distinction into lexical and grammatical type along with the subclassification of each into various cohesive devices from reference to substitution and from repetition to collocation. Recent perspectives on cohesion analysis are likely the development of the immediate theory proposed by Halliday and Hasan (1976) to which new ideas from different viewpoints have occasionally been added. 


\section{Studies on cohesion}

There have not been many studies on cohesion and coherence found in the literature. One that highly resembles this research is the analysis of cohesion in Javanese Facebook conversations made by Sukoyo (2010). Sukoyo found that various cohesive markers were frequently used in Javanese conversations on Facebook comprising reference, substitution, ellipsis, and conjunction from grammatical category as well as repetition, synonymy, antonymy, collocation, and equivalence from lexical category. However, this study has a defect in its scope of analysis that was limited to intrasentential cohesion or cohesion within sentences only without considering the general structure of discourse which consists of a number of sentences or utterances with connected meanings.

The objects of former research on cohesion and coherence were mostly in the forms of conventional discourse from the actual world, either in written or spoken form. Munandar (2010), for example, analyzed the rhetoric structure of PRD (Democratic People Party) pamphlets to comprehend the coherence of the discourse based on the coherence theory from Ramlan (1993) and rhetoric structure from Coulthard (1996). The result showed that the pamphlets of the political party used persuasive strategies by following situation-problemsolution pattern of ideas for building the coherence of the texts.

Then, by her research on conjunctional cohesion in narrative discourse of Torajanese language, Jerniati (2010) found that there were only six types of conjunctions that were used to build the unity of narrative discourse in Torajanese folklores. Those six different conjunctions were addition (e.g. anna, susimoto), temporal (aparaya, sitaruqna, mane, iatnona, katappuanna), conclusive (dadi), conditional (iake), validity (iamoto), and causality (sabaq).

Another study of cohesion and coherence in a local language has also been conducted by Suryaningsih (2014) with the object Lintang, a Javanese novel written by Ardini Pangastuti $\mathrm{Bn}$. The findings showed that Javanese grammatical cohesion in the story was manifested by personal references (aku, sliramu, dheweke), demonstrative references (sawijining ndina, sesuke, saben minggu), substitutions (wong loro), ellipses (tanpa kowe, novele, sanajan), and conjunctions (nanging, sanajan, merga). On the other hand, the coherence between sentences within the story was realized by cause-effect, reason-causal, facility-purpose, condition-result, term-result, comparison, and time additional (simultaneous and consecutive) relation.

In contrast with the above previous studies with written forms as the objects of research, Schriffin (1985) conducted a study on spoken language. In her article Conversational Coherence: The Role of Well, she insisted that well, as a discourse marker, would help the speaker along with his/her utterance to position themselves in the ongoing conversational construction since not all of the available references were noticed simultaneously. The result of daily conversation analysis showed that well connected the speaker to a system of conversation between two parties when the option provided by previous reference toward the subsequent coherence was not completely achieved. Therefore, the word well was considered significantly influential in the informational structure of questions, answers, conditions underlying requests and various shifts of participation within conversations.

Next, by their research on lexical cohesion in political speech, Klebanov, Diermeier \& Beigman (2008) tried to analyze Margaret Thatcher's speech at Conservative Party Conference by using automatic lexical cohesion detector to identify the primary domain of semantic origin of the speech. The research concluded that lexical cohesion analysis was a potential technique to 
bridge the gap between quantitative and qualitative textual analysis toward political contents by determining established units for making comprehensive and coherent coverage which supported direct interpretations.

Meanwhile, Gomez (2010) introduced the term 'associative cohesion' to complete formerly established cohesive types when he investigated lexical cohesion of 15 telephone conversations in England. The result of the investigation showed that all the telephone conversations were lexically cohesive which came from repetitions $(52,6 \%)$, associative cohesion, and inclusive relations $(10,5 \%)$. These cohesive relations were mostly distributed in turn-takings $(87,6 \%)$ and mediated remote span $(71, \%)$. In addition, the lexical patterns found in the conversations demonstrated a relationship with topical management process and were influenced by particular genre-related factors as well.

Another study on spoken discourse has managed by Anjani (2013) who compared discursive cohesion and coherence between Indonesian and French stand-up comedy. She found that both Indonesian and French stand-up-comedy discourse utilized either grammatical or lexical cohesive devices. The former comprised personal, demonstrative, and comparative references as well as substitutions, ellipses, dan conjunctions, whereas the latter included repetitions, synonymy, antonymy, and collocations. On the other hand, the applicable coherence devices consisted of additional, temporal, contrastive, causal, resultative, concessive, and conditional relation of meanings.

Almost similar to the previous studies above, the formal object of this research was discourse unity. However, the topic of this research was limited to cohesion only since the existence of cohesion as a discourse marker - particularly in spoken form - has always been initiated by the availability of coherence within the text. In other words, coherence can be seen as the basic requirement for the existence of cohesion. It is merely because both are two important elements that build the unity of a text. Meanwhile, the material object of this research was Facebook conversations, a popular social media discourse in the Internet. The analysis was restricted to conversations produced by Indonesian users who basically used Indonesian language without ignoring any interference from other local or foreign languages.

\section{RESEARCH METHODS}

As a type of descriptive research, this study aimed at describing the system of cohesion in Facebook conversations by identifying the composition and distribution of cohesive markers within the units of discourse to find out the role and contribution of each in building unity as well as giving characters to the discourse.

To be the source of the data was the researcher's personal Facebook account which provided lots of conversation units from different parties who have been confirmed as his friends. Both qualitative and quantitative data were obtained in this research. The former were in sort of words, phrases, and clauses which functioned as cohesive markers whereas the latter were constituted by numbers resulted from the calculations of each cohesive marker's appearances across the texts.

Meanwhile, since this research was basically qualitative in nature, the researcher acted as the main instrument, that is the one who was responsible for collecting and analyzing the data as well as drawing the conclusions and writing the report of this research. As the supporting 
instruments, computers, internet connections, Facebook accounts, and reference materials in either printed or electronic forms were utilized.

For collecting the data, two different techniques were applied, namely observation and documentation. The observation process was made by carefully watching and comprehensively reading as many as Facebook conversation units of population to obtain the research samples. To determine the samples, purposive sampling technique was applied by choosing as many as 100 units of conversations whose characteristics met the criteria stated for this research. The selected conversation units were then documented as copies of text files for analysis purpose.

The process of analysis itself involved conversation and semantic analysis. Conversation analysis was applied to determine the components which constructs the structure of Facebook conversational discourse. Meanwhile, semantic analysis was purposed to capture the relation of meanings between the messages that made up the conversations. The combination of these two processes of analyses resulted in an identification of both types and numbers of the language units (i.e. words, phrase, and clauses) functioning as cohesive markers within the research samples. These results of analyses were then put as the bases in formulating the characteristics of the discourse.

\section{FINDINGS AND DISCUSSION}

Based on the observation, all the cohesive markers - from the grammatical to the lexical and from references to collocations - could be found in Facebook conversations. However, the compositions and distributions of the cohesive markers were different from one to the other unit of the discourse. The result of calculations showed that the cohesive relations within Facebook conversations were dominated by the high existence of reference (REF), ellipsis (ELL), repetition (REP), and conjunction (CON). Other cohesive relations, such as substitution (SUB), synonymy (SYN), antonymy (ANT), hyponymy (HYP), and meronymy (MER), equivalence (EQU), and collocation (COL) seemed to have less contributions to the cohesiveness of the discourse due to their low appearances across the texts. The average distribution of the cohesive markers in Facebook conversations can be seen in the Chart.

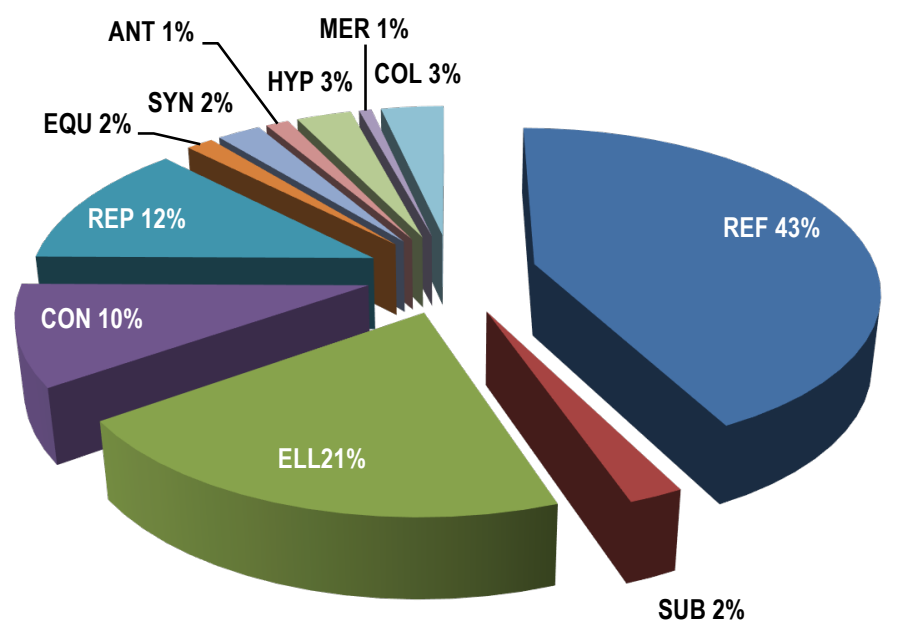

Chart 1: The distribution of cohesive markers in Facebook conversations 
The numerous appearances of references in Facebook conversations were considerably supported by the existence of different types of relations under referential cohesion category, such as demonstrative, personal, locational, temporal, and comparative reference. Nevertheless, the distribution of these kinds of references in texts were not comparatively equal one to others. From its quantity, personal reference can be considered to be the most significant one overcoming the others. In Indonesian language, personal references are generally realized by personal pronouns, such as aku, kamu, dia, and kita. It did apply in Facebook conversations as the following.

N : Jalan Terbaik Menerima Takdir adalah Memaafkan \& Berbesar Hati (The best way to accept destiny is forgiving and being generous)

DW : Status yang kereeen (A nice status)

\section{$\mathrm{N} \quad$ : Kita ambil hikmah bersama dek}

(We take the lesson together, sis)

In the excerpt, the referential cohesive relation is marked by the word kita (we), a personal pronoun for first person plural which refers to both $\mathrm{N}$ and DW, the two participants of the conversation.

Nevertheless, in a conversation particularly, the function of personal reference is often worked out by vocatives, typical words or phrases used to summon. The vocatives used in Facebook were not totally different from those of direct conversations. Formal summons such as pak (mister), bu (madam), and kak (brother/sister), as well as the informal ones, e.g. bro, cin (luv), and gaes (guys) are found in the data. The only difference lies in the availability of mention, a tool for summoning another user that is provided by the system.

SWB : gawean lawas (old job)

BE : Gaweanmu sak iki penak, lahan basah, yo ra pak $\underline{\mathbf{L A H}}$,, (your current job is comfortable, wet area, isn't it mister LAH)

LAH : Genahh kuii ngnoo 200 ewu..jek jupuk neng blimbing..wkwkwkkk (True, it is so 200 thousand ... still picking from starfruit..wkwkwkkk)

In the example above, the phrase pak $L A H$ has the functions of both summoning and mentioning. The word pak (mister) constitutes a summon for an elderly man, whereas $L A H$ is an account name referring to one participant of the conversation. This vocative has created a referential cohesive relation between the last two messages.

The frequent use of personal references, especially first and second person pronouns as well as vocatives, strongly characterizes Facebook conversations as a typical of interactive discourse that involves multiple participants who actively communicate by sending textual messages to one another. From the perspective of text unity, Facebook conversations can also be termed as having interpersonal cohesion from the existence of these kinds of references.

Meanwhile, the existence of other references in Facebook conversations were not as high as personal references. Demonstrative references, for example, were just occasionally found in texts by the presence of the words ini (this), itu (that), and their variants. The following is one of the cases. 
NR : Mengapa banyak orang jahat di dunia ini

(Why are there many bad people in this world)

Apa memang inginnya begitu

(Do they want so)

Atau memang peran di dunia harus jadi orang jahat...

(Or maybe their roles should be bad people...)

M :Itulah sebabnya cin neraka penuh.surga jd lega dech.wk wk wk

(That's why hell is full, luv. Heaven becomes airy ok. wk. wk. wk)

In the excerpt above, a demonstrative reference occurs involving the word itu (that) which points to the clause banyak orang jahat di dunia ini (there are many bad people in this world). This reference builds a cohesive relation between the two parts of conversation. However, in most cases of demonstrative referencing, the referents were mostly in the forms of nouns instead of clauses or verbs.

Locational and temporal references were rarely found in Facebook conversations since the availability of information on place and time was not always necessary. Even when such information was present, it commonly appeared once and was almost never referred to in other parts of the discourse. The following is one of the few occurrences of locational and temporal references in FB conversations.

IL :Ning kene 10 ewu jujul mbk, hehe

(Here 10 thousand still gets return sis, hehe)

PI : es kobar kartasura ya .... malah lbh banyak sisan

(kobar ice Kartasura, isn't that? ... it's even more)

A cohesive relation by locational reference occurs in the part of conversation above involving the adverb of place ning kene (here) as the referer and es kobar kartasura (kobar ice Kartasura) as the referent. Aside from exemplifying locational reference, the relation also indicates cataphoric reference since the position of the referent is right after the referer. To some extent, the existence of the locational and temporal reference as what exemplified above contributed to the topical cohesiveness of Facebook conversations since it took over the role of repetition in linking two separated messages with place and time information.

When compared to other referential cohesive markers, comparative references might be the least to perform. Naturally, people do not have to make comparison every time they have conversations. Therefore, the demand of using comparatives such as 'the same with' or 'more than' are not so many in comparison to the demonstratives or personal pronouns. An example of this phenomenon is as follows.

$\mathrm{N}$ : Bilang samo Dilan 90, yg berat itu angkat besi. hah hhh

(Tell Dilan 90, the one that's heavy is weightlifting. hah hhh)

PT : RB, lebih berat mneh menurunkan berat badan say

(RB, it's even heavier to lose bodyweight, darl) 
In the text above, there occurs a comparison between angkat besi (weightlifting) and menurunkan berat badan (to lose bodyweight) which is facilitated by the phrase lebih berat (heavier) to state that the latter is harder to do than the former.

Even though the total appearance of ellipses in Facebook conversations was quantitatively lower than that of references, the contribution given by the former in building cohesion can be considered higher than that of the latter. It is because, unlike references, ellipses do not subordinate many cohesive relations. Based on the language units they omit, ellipses can be distinguished into three categories only, i.e. nominal, verbal, and clausal ellipses. The following is an occurrence of ellipsis in Facebook conversations.

N : (Aku) Kangen touring malam ke situ sama kawan", padahal cuma_mau sekedar ngopi,ngumpul,ngobrol

(I) miss night touring there together with my friends, although only for drinking coffee, gathering, chatting

DW : (Kamu) Puasa mudik kan..

(You) in fasting month go home, don't you?

In both messages of the conversation above, there are two ellipses of sentence subjects which are constituted by two contrastive pronouns, namely aku (I) and kamu (you). Both of these omitted parts refer to $\mathrm{N}$ as one participant of the conversation. These ellipses implicitly indicate the existence of a cohesive relation between the two messages. From the three categories of ellipsis, nominal ellipses show its dominance toward the rest whereas subjects or participants became parts of sentences which commonly underwent elliptical process.

Such massive presence of ellipses demonstrates that the messages in Facebook conversations were commonly delivered through informal mode of discourse. It is because the omissions caused by ellipses resulted in incomplete sentences without participants, processes, or circumstances and establishing a non-standard variant of language. At the same time, the existence of many ellipses along the lines of conversations also indicated the availability of coherence in terms of mutual understanding between the participants.

The next significantly influential cohesive markers in Facebook conversations is repetition. Different from references and ellipses which can be categorized as grammatical cohesive relations, repetition represents lexical cohesion within a text. Therefore, it can be stated as the most dominant cohesive markers from lexical category. One of the many cases of repetitions within Facebook conversation can be illustrated as follows.

$\mathbf{N}$ : Touringnya lebih asik pke' trail

(The touring will be more enjoyable by using trail)

DW : X Ridenya dibawa dong

(Bring your X Ride then)

$\mathrm{N}$ : Kapan ready nya..

(When are you ready?)

DW : Kamis /jumat setelah tarawih

(Thursday/Friday after tarawih (Muslim prayer in the month of Ramadhan)

N : Touring $T W$.

(Touring TW) 
DW : ...??? Hari itu touring Jakarta-Solo

(...??? That day is Jakarta-Solo touring)

$\mathrm{N}$ : Sekalian touring KRA-TW aja ntr klo mudik

(Go along with touring KRA-TW next time you go home)

DW : Ya ntar kawan" kalo ngumpul

(Ok later when my friends gather)

$\mathrm{N} \quad$ : Coba touring nya smpe Bangka

(If only the touring reaches Bangka)

In the conversation above, four times of repetitions occur on the word "touring". These repetitions explicitly indicate the topic of conversation in which the word "touring" acts as the cohesive marker that guarantees the unity of the discourse.

Conjunctive relations as a kind of cohesive markers could also easily be found across Facebook conversational texts. However, they were likely not realized by typical conjunctions commonly used in writing, such as additives, contrastives, comparatives and so on. Instead, the actions were taken by language units expressing confirmations and interjections, as shown in the following.

NHH : Bzok tasx z bwa ya k sekolah?

(Tomorrow, please bring $\mathrm{z}$ bag to school, ok?)

IL : okee bu ...duitnya tunggu gajian ya bu ..boleh kah su abis bw natalan jadi

(ok mom ... about the money you wait till salary payment, alright mom ....may I do so after Christmas)

NHH : Iya tdk ap2 bu. .

(Alright never mind, mom)

Two conjunctive relations occur on the excerpt of conversation above as marked by the words okee (ok) and iya (yes). Both of these words have the functions of confirming as well as linking messages in the text.

In the same way, the interjection Lha in the following example also acts as a conjunction which connects two consecutive messages Ini masih sendal (It's just sandals) and knpa mas? (why bro?).

MH :2 pasang sandal sdh hilang! Yg satu kemarin setelah yasin tahlil yg satu td sepulang dr masjid sdh ndak ada! Hadehhhjjjjj

(2 pairs of sandals are gone! One was gone yesterday after yasin tahlil [prayer for the deceased] and the other just now after going home from the mosque, they have disappeared! Hadehhhjjjji)

HB : Ini masih sendal,....

(It's just sandals ,....)

MH : Lha knpa mas?

(Lha why bro?) 
However, the action performed by the conjunction in this case is not a confirmation but an expression of wondering. Other similar cases in which interjections acted as conjunction shown by the expressions of nah, lho, wah, weleh etc. with their own specific meaning. Thus, these confirmative and interjective expressions can be considered as typical conjunctions in conversations.

Out of the four cohesive markers, substitution, equivalence, synonymy, antonymy, hyponymy, meronymy, and collocation demonstrated less significant contributions to the cohesiveness of Facebook conversational texts. Generally, it is because the demand for using these cohesive markers are not as high as that of reference, ellipsis, repetition, and conjunction. Few cases of the use of each can be examined in the following descriptions.

\section{EY : Kata si asap tiada maaf bagi mu}

(Asap said there's no forgiveness for you)

\section{$\mathrm{AL}$ : Bara yang bilang gitu dek}

(It was Bara who said so, bro)

In the excerpt above, a substitution occurs to the clause tiada maaf bagi mu (no forgiveness to you) which is replaced by the word gitu (so) in the subsequent message. Similar to common face-to-face conversations, the words begitu and begini, along with their variants, have become the typical expressions for making substitution in online conversations on Facebook. To some extent, the rarity of substitution within the texts were partially caused by the high existence of ellipsis since both have almost the same function. Ellipsis can be counted as a zero substitution. Aside from that, the role of substitutive cohesive markers has sometimes been replaced by the demonstrative references ini and $i t u$.

Even though equivalence has much resemblance to repetition, the appearances of these two cohesive markers in Facebook conversations were not comparable. Only few cases of cohesive relation by equivalence were found in the research samples. One them can be seen below.

\section{SBJ : Luar biasa murobi satu ini... bacaannya berkelass..}

(How great this murobi ... his reading has a high quality..)

BE : Untuk perpus masjid, biar jamaah yg baca,, Saya bagian beli saja,,,

(For the library at the mosque, let the community read, My responsibility is for purchasing only)

In the conversation above, equivalence occurs between the words bacaan (readings) and baca (read) since both have the same root despite their different word classes. Bacaan is a noun whereas baca is a verb. Some experts include equivalence into repetition due to the high similarity of the process, that is renaming the same word.

Synonymy is another cohesive relation that is nearly similar to repetition. Unlike repetition, the sameness in synonymy does not lie in the word spellings but in the meaning only. An example of synonymous relation in Facebook conversations can be seen in the following excerpt.

NR : Ora popo cin. Yen anakku pengalaman dgn alam. Menyatu dgn alam. Jare malah gayeng 
(Never mind, luv. My daughter already has some experiences with nature.

Integrating with the nature. She said it was very enjoyable)

M : Walah wong tuo melok sir"an to kdang bocah mlah seneng krn pengalaman y cin.y mugo"ae waras slamet gakenek opo" cin

(Walah when parents are worried sometimes children are just happy because of having experiences, isn't it lov. Hopefully they are healthy and safe and nothing happens, luv)

BP : Amin... Berdoa saja say ... Agar slalu diberi keselamatan buat putrinya ..... (Amen... Just pray, darl ... For the sake of your daughter's safety ...)

Two cases of synonymy occur in the text above involving three different words, namely anak (child), bocah (kid), and putri (daughter). Even though these words are different in spelling, they have nearly similar meaning since they all refer to child or a person at a very young age except the third one which also contains information on the gender and kinship.

Synonymy can be seen as the alternative of repetition. Therefore its emergence in Facebook conversation was not as frequent as the latter. Logically, in a conversation which is made in a limited time and spontaneous manner, participants will tend to choose using exactly similar words instead of searching for another different word when they want to re-express the same meaning.

Unlike other forms of reiterations, such as repetition, synonymy, hyponymy, and meronymy which constitute similarities or subordinations, antonymy represents an opposition of meanings between two language units. Therefore, its emergence in conversations, including on Facebook, is likely fewer than the others. Simply, it is because, in a conversation, a discussion on opposition is not always necessary. One of the few cohesive relations by antonymy in Facebook conversation is illustrated below.

MH : Mau buat alas kandang! Adàkah yg puny kayu2 bekas buat alas kandang mbek (Want to make a stall mat! Anybody has secondhand wood for the goats' stall mat)

\section{BR : Toko bangunan}

(Building material store)

MH : mahal pak

(Expensive, Sir)

FRZ : Mao yg murah

(Want the cheaper one)

A relation of antonymy occurs between the word mahal and murah. Both are contrastive adjectives dealing with price levels. Mahal means high price or 'expensive' whereas murah constitute lower price or 'cheap'

To some extent, hyponymy and meronymy have a similarity in terms that they both indicate a subordinative relation. When the former involves a relation between group and its member the latter deals with an entity with its components. The directions of these relationships can be up, down, or parallel. However, when the appearances of these two forms of subordinative reiterations in Facebook conversations were compared, hyponymy showed 
dominance toward meronymy. The cases of cohesive relations by hyponymy and meronymy can be described as follow.

MH : Impor bawang putih- masakan apa yg ndak bth bawang? (Import white garlic- what food needs no garlic?)

MH : Sy kok ndak tahu ya klo ada bawang lokal? Bawangnya spt apa ya? (Why don't I know there's local garlic? What does the garlic look like?

BT : Apa betul bawang putih import?

(Is it true that white garlic is imported?)

In the excerpt above, a relation of hyponymy happens among three linguistic units, that is bawang (garlic) as the superordinate and bawang lokal (local garlic) along with bawang putih (white garlic) as the subordinates. These relations definitely contribute to the cohesiveness of the conversational text.

Likewise, the words buku (book) and perpus (library) build another cohesive relation in the following excerpt of conversation. However the relation is considered as meronymy rather than hyponymy since book is an inseparable part of library. In other words, there is a whole-part relation between perpus and buku.

EA : Banyak nabung banyak beli buku. Kebaca? Entahlah haha (Often save money, often buy books. Readable? Dunno haha)

EA : Buat bantal dit hehe (For money pillow hehe)

SAE : mbok yo di ampil2 no kancane nu ngopoooo... timbang mubaziiiiirrrr (Why don't you lend them to your friends ... instead of useless)

EA : Mengko yen perpus $k u$ wis dadi yo tri, nyileh rapopo hehe

(Next time when my library is completely ready, Tri, you can borrow them, never mind, hehe)

Even though hyponymy appeared more frequent than meronymy, both existence across Facebook conversations was considerably lower compared to that of repetition. It is because, hyponymy and meronymy were necessarily purposed for showing subordinations, giving examples, listing series of items, and showing whole-part relations only.

Lastly, although having more flexible and wider scope of relations than other lexical cohesive markers, collocation did not contribute much in building the cohesion of Facebook conversations either. It is because some of collocative relations could be more precisely included into other cohesive relations. Other than that, grammatical relations between words or phrases in separated messages rarely occurred in the conversations. The following is an illustration of collocative relation in a Facebook conversation.

VL : Generasi 80an akhir dan 90an, kapan kalian terakhir pakai sistem operasi ini di komputer? Waktu itu komputer masih model built-in monitor dan cpunya. Kapasitas hardisk masih kurang dri 8 GB. Huh.. Time flies..

(Generation of late $80 \mathrm{~s}$ and $90 \mathrm{~s}$, when did you last use this operation system on your computer? At that time a computer was still a model of built-in monitor and CPU. Its hard disk capacity was lower than 8GB. Huh.. Time flies..) 


\section{VL : Trus kedengaran suara aneh di komputer wktu loading dan indikator lampu booting kedip 2 AIC}

(Then, (you) heard a ridiculous sound from the computer when it's loading and the booting indicator lamp was blinking AIC)

In the conversation above, two collocative relations occur involving three different words, i.e. komputer (computer), 'loading', and 'booting'. These relations can be seen from two different perspectives. First, the three words come from the same field, that is technology - or in more specific - computing. Second, logical structure of sentences can be constructed from the three words as in 'computer is loading' and 'computer is booting'.

\section{CONCLUSION}

Generally, all types of cohesion could be found in Facebook conversations either grammatical or lexical and from reference to collocation. However, their distributions were different from one another. Grammatical cohesion is likely dominated by the numerous appearances of reference, ellipsis, and conjunction. From referential cohesive markers, the massive use of personal pronouns (especially of the first and second person) and vocatives (i.e. summons and mention) indicated Facebook conversations as typical of interactive discourse which involve multiple participants. Meanwhile, the high frequency of ellipsis in the conversations represented an informal mode of discourse made by the participants since it resulted in lots of incomplete sentences as well as non-standard variants of language. In addition, conjunctive cohesive markers also contribute much to both interactive and informal characteristics of Facebook conversations by the existence of particular linguistic units functioning to link between messages, such as interjections and confirmations, which were very different from conventional conjunctions commonly used in writing.

Meanwhile, the insignificant appearances of substitution, equivalence, synonymy, antonymy, hyponymy, meronymy, and collocation in Facebook conversations were generally caused by the demands for using these cohesive markers which were not as high as the dominant ones. The role of substitution has partially taken over by demonstrative references and ellipses whereas synonymy seemed to be an alternative for repetition only. Likewise, the use of antonyms was also limited since not every conversation includes a discussion on oppositions. In the same way, the function of hyponymy and meronymy was restricted for describing a subordination between objects only, as in giving examples or naming the components of an entity. As for collocation, the relation typical to this - i.e. between words from the same field has immediately been accommodated by other cohesive markers. In addition, structural relations between words in separated messages were rarely found as well.

\section{NOTE}

The authors would like to thank two anonymous reviewers for their helpful comments on the earlier version of the paper. 


\section{REFERENCES}

Anjani, E. A. (2013). Kohesi dan koherensi wacana standup comedy Prancis dan Indonesia. Kawistara, 3(3): 227-334.

Boyd, D. M. \& Ellison, N. B. (2008). Social network sites: definition history, and scholarship. Journal of Computer Mediated Communication. 13: 210-230.

Carr, C. T. \& Hayes, R.A. (2015). Social media: Defining, developing, and divining. Atlantic Journal of Communication. 23: 46-65.

De Beaugrande, A. (1981). Introduction to discourse. London: Longman

De Beaugrande, A. \& Dressler, W. (1981). Introduction to text linguistics. London: Longman.

Halliday, M.A.K. \& Hasan, R. (1976). Cohesion in English. London: Longman Group Ltd.

Halliday, M.A.K. \& Hasan, R. (1985). Bahasa, teks dan konteks (Trans: Asruddin B. Tou). Yogyakarta: Gadjah Mada University Press.

Halliday, M.A.K. \& Matthiessen. (2004). Introduction to functional grammar. New York: Routledge.

Hoey, M. (1991). Patterns of lexis in text. Oxford: Oxford University Press

Holt, R. (2004). Dialogue on the Internet: Language, civic identity, and computer-mediated communication civic discourse for the third millennium. Westport: Greenwood Publishing Group.

Jerniati, I. (2010). Kohesi konjungtor dalam wacana narasi bahasa Toraja. Humaniora, 22(1): 94-101.

Klebanov, B. B., Diermeier, D. \& Beigman. E. (2008). Lexical cohesion analysis of political speech. Political Analysis, 16 (4): 447-463.

Martin, J. (1992). English text: System and structure. Amsterdam: John Benjamins.

Munandar, A. (2001). Analisis struktur retorika: alternatif memahami koherensi wacana selebaran Partai Rakyat Demokratik. Humaniora, 13(2): 150-163.

Rohmadi, A. (2016). Tips produktif ber-social media. Jakarta: PT Elex Media Komputindo.

Statcounter: GlobalStat. (2019). Social media stats in Indonesia - June 2019. http://gs.statcounter.com/social-media-stats/all/indonesia. (Diakses 16 Juli 2019).

Statista. (2019a). Global social networks ranked by numbers. https://www.statista.com/statistics/272014/global-social-networks-ranked-by-numberof-users/ (Diakses 16 Juli 2019).

Statista. 2019b. Top 15 countries based on number of Facebook user. https://www.statista.com/statistics/268136/top-15-countries-based-on-number-offacebook-users/. (Diakses 16 Juni 2019).

Schriffin, D. (1985). Conversational coherence: The role of well. Language, 61 (3): 640-667.

Sukoyo. (2010). Analisis wacana percakapan berbahasa Jawa di jejaring sosial Facebook: Kajian kohesi. Widyaparwa 40(2): 21-28.

Suryaningsih, R. (2014). Kajian kohesi dan koherensi dalam novel Lintang karya Ardini Pangastuti Bn. Jurnal Program Studi Bahasa dan Sastra Jawa, Universitas Muhammadiyah Purworejo, 5(2): 46-51. 
Thompson, G. (2014). Introducing Functional Grammar. Oxon: Routledge

Thurlow, C., Lengel, L. \& Tomic, A. (2004). Computer Mediated Communication: Social Interaction and the Internet. London: SAGE Publications.

Widdowson, H. (1978). Teaching Language as Communication. Oxford: Oxford University Press. 